\title{
Dos poemas $y$ unos cantares de Darío no recogidos por Méndez Plancarte
}

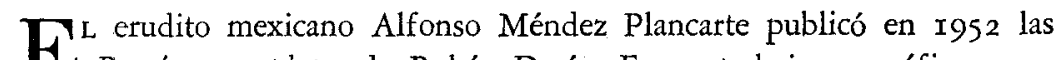
1 Poesías completas de Rubén Darío. Es un trabajo magnífico, pues en ese volumen están comprendidos no sólo los poemas darianos que el compilador logró reunir y que no habían sido publicados en anteriores ediciones, sino también un estudio bibliográfico de estos poemas y una crítica de las anteriores compilaciones incompletas que hasta ese año habían aparecido.

Pero como la obra de Darío se difundió tanto y sus poemas aparecieron en tan diversas revistas y periódicos así de España como de nuestros países de América, quedan siempre algunas piezas - no de las más importantes, por supuesto- que se han escapado a los compiladores de la obra dariana.

En un viejo álbum de recortes que perteneció a Rafael Heliodoro Valle he encontrado algunos poemas de Darío junto con los de otros paetas contemporáneos suyos. Comparándolos, uno por uno, con los que aparecen en las Poesias completas de Méndez Plancarte, noto que faltan, entre éstas, las dos siguientes pequeñas composiciones poéticas $y$, además, en un número de La Noticia, de Managua, del $\mathrm{r} 6$ de febrero de I9I6, No I00, p. 4, * algunos de los "Cantares del Cardón", que Méndez Plancarte no logró completar por no haber tenido a la mano ese número del diario nicaragüense.

[* En un memorándum de Méndez Plancarte a su colaborador Ernesto Mejía Sánchez se lee: "Me urgen, de Nicaragua: ... Varios cantares de R. D. (que no sé si estarán todos recogidos): en La Noticia, de Managua, 1916, No 100. tescribí sobre ellos al Dr. D. Juan Ramón Avilés, y no he tenido respuesta". Afortunadamerte hoy puede suplirse ese silenciol. 


\section{Dos POEMAS}

Los breves poemas no recogidos y hallados casualmente, son los siguientes: el primero, fechado en I906 se titula "Souvenir":

$$
\begin{aligned}
& \text { Va la vela blanca } \\
& \text { bajo el cielo azul } \\
& \text { y en el mar amante } \\
& \text { de mi mente, tú! } \\
& \text { Sople buena brisa } \\
& \text { brille alegre el sol } \\
& \text { y que digan aguas } \\
& \text { y cielos: Amor! }
\end{aligned}
$$

Rubénz Dario.

El segundo poema se titula "El ánfora" y, Méndez Plancarte seguramente no lo conoció, por haber sido publicado en revistas de escasa circulación. Rafael Heliodoro Valle lo publicó en Poetas modernos de Centro-América. Selección y Glosario, que apareció quizá en I9I8 ó I9-19, o tal vez antes. En la tarjeta que hay en la Biblioteca del Congreso de Washington, aparece dentro de un mismo volumen con El anecdotario de mi abuelo, que se publicó en I9I8, como sobretiro de la revista Tegucigalpa y no en I9I5, como se lee en esa tarjeta. Los ejemplares de la publicación de R.H.V. carecen de fecha y de cualquiera indicación, e incluso aparecen en forma anónima, pero esa selección fue hecha por R.H.V.

Este soneto ha aparecido recientemente en el libro de Diego Manuel Sequeira Rubén Darío Criollo en El Salvador (León, I964, P. 5I) y lice que se publicó en $E l$ Tren, de Tegucigalpa (Honduras) el 5 de diciembre de I889, Seriè III, No 30, p. 3 , y es como sigue:

\section{El anfora}

Yo tengo una bella ánfora, llena de regio vino, que para hacer mis cantos me da fuerza y calor; en ella encuentra sangre mi corazón latino para beber la vida, para latir de amor.

Grabó en ella un artífice, con su buril divino, junto a una viña virgen, a Baco y su esplendor, y a Pan, que enseña danzas, el rostro purpurino, a cabras y pastores bajo un citiso en flor. 
El ánfora gallarda contiene la alegría;

Dionisio su carquesio sobre ella derramó;

el sátiro gallardo su aliento, su armonía

y Venus, una perla que en sus cabellos vio.

El vino rojo tiene mi luz, mi poesía:

quien lo hace, son los dioses, y quien se embriaga yo.

Rubén Dario.

\section{Los CANTARES deL CARDóN}

En cuanto a los "Cantares del Cardón" voy a presentar aquí algunos de los que no aparecen en las Poesias completas, ni en Laurel solariego, publicado en Managua en 1909 por Juan B. Prado. El conocimiento de esta última obra lo debo a don Edelberto Torres, quien gentilmente me la proporcionó para hacer la comparación.

En La Noticia, de la fecha ya citada, se dice que los originales de estos cantares son propiedad de doña Margarita de Lacayo. Méndez Plancarte presenta en su compilación ro estrofas, mientras que en la Noticia aparecen r7. Llevan el títilo siguiente:

\section{Inéditos de Rubén Dario}

Una diadema florida Te brinda un Emperador Emperatriz de mi vida, Emperatriz de mi amor.

¿Por qué tanto pensat

Si en esta cosa tan pura Saboreamos la amargura La amargura de la mar?

Los cabellos son de oro Y la faz de rosa té. Ella le dijo: Te adoro. Y él: jamás te olvidaré.

No me repitas que existe El remedio del amar La princesa estaba triste, No se pudo consolar.
(Esta estrofa aparece en Poesias completas, correspondiendo a la 5a. allí citada. En vez de "Por qué", dice alli "Para qué").

(Esta estrofa aparece en Laurel solariego y en las Poesias completas, correspondiendo en éstas a las 2a. allí citada). 
La paloma está dormida ¿Qué te dijo su canción? Canta sólo en esta vida

Una vez el corazón.

Vida mía, vida mía, Qué divina está la mar, ¿Cómo no supe aquel día

Que me habias de olvidar?

Muy cerca está el milano $Y$ muy cerca la canción Vámonos mano en la mano, Corazón con corazón.

Estoy llorando con mengua

$Y$ sufriendo sin razón.

Puesto que he hecho de mi lengua

Carne de mi corazón.

Muy linda contestación ¿Una mañana de Mayo

Cómo te llamas, canción? ¿Yo? Margarita Lacayo.

Está ardiendo mi incensario

En una copa de ofir

Navegar es necesario

$\mathrm{Y}$ es necesario vivir.

Me dan los vientos su aliento

$\mathrm{Y}$ sopla mi voluntad

Sé tu propicio; joh viento,

A la barca de Simbad!

Me dijo la onda del río:

Es meterse a santo o fraile

Llamarse Rubén Darío

O Ilamarse Luis Debayle.

Mi nombre mité en la arena

$Y$ no lo quise borrar

Para dejarles mis penas

A las espumas del mar.

¿De dónde vienes mi vida?

Vida mía, ¿dónde vas?

Voy a curarme esta herida

Que no se cierra jamás.
(En Poesias completas, correspondiente a la 6a. estrofa allí citada, pero en vez de "La paloma", empieza por "Filomela").

(En Poesias completas, correspondiente a la estrofa 7a.)

(En Poesias completas, correspondiente a la estrofa 9a.)

(En Laurel solariego y en Poesias completas correspondiente a la estrofa 3a.)

(En Poesias completas, correspondiente a la estrofa 10a.)

(En Poesías completas, correspondiente a la estrofa 8a.)

(En Laurel solariego y en Poesías completas correspondiente a la estrofa 1a.)

(En Poesias completas, correspondiente a la estrofa 4a.) 
Hay cosas que yo no entiendo

En este triste vivir

Me estoy muriendo, muriendo

$Y$ no acabo de motir.

Desde que aspiré tu esencia

He perdido la razón

$\mathrm{Ya}$ no tengo ni conciencia

Ni vida, ni corazón.

Estas cosas dolorosas

Que pasan entre los dos...

Oh Dios! arregla estas cosas

O no voy a creer en Dios!

Una estrella está cantando $Y$ otra estrella le responde

$Y$ la una dice ¿cuándo?

Y la otra contesta, ¿en dónde?

A continuación de éstos, aparecen los versos compuestos por el Dr. Luis Debayle, con que contesta a Darío.

Emilia Romero de VALle

México, D. F. 
